А.М. Кривоножко ${ }^{1}$, В.М. Романюк ${ }^{2}$, М.В. Дудко ${ }^{3}$, Д.В. Руденко ${ }^{4}$

${ }^{1}$ Повітряне командування “Центр”, Васильків

${ }^{2}$ Головна інспекція Повітряних Сил Головної інспекції Міністерства оборони України, Київ

${ }^{3}$ Харківський національний університет Повітряних Сил ім. І. Кожедуба, Харків

${ }^{4}$ Украӥнська інженерно-педагогічна академія, Харків

\title{
МЕТОД НАВІГАЦІЇ БЕЗПІЛОТНОГО ЛІТАЛЬНОГО АПАРАТУ ПРИ ВИКОНАННІ ЗАВДАНЬ ЗА ПРИЗНАЧЕННЯМ
}

\begin{abstract}
Використання безпілотних літальних апаратів під час виконання різнорідних завдань за призначенням вимагає розроблення додаткових механізмів захисту їх від впливу радіоелектронних перешкод, погодних умов та підвищення безпеки польотів в зоні виконання завдань. Одним з підходів зменшення вразливості безпілотного літального апарату є використання інериійних засобів навігаџії. Додатково до них можуть використовуватися методи обробки зображення, щчо отримуються підсистемою оптичного орієнтування, для очінки параметрів руху та виробки управляючих впливів. У статті запропоновано метод навігації безпілотного літального апарату для очінювання динамічних параметрів руху за даними, отриманими оптичною підсистемою. У даній роботі запропоновано адаптивний метод визначення параметрів вектору руху безпілотного літального апарату, щз реалізує процедуру адаптивної зміни розміру і стратегію пошуку вектору руху, щчо залежить від структури блоку зображення та його властивостей. Проведено аналіз існуючих методів оцінки параметрів вектору руху на основі обробки оптичних даних. Проведено формальний опис оптичного потоку та визначено прочедуру його отримання. Визначено склад алгоритмів для обробки оптичного потоку. Обгрунтовано вибір блокового алгоритму оцінки руху. Блокові алгоритми є вигідним компромісом по співвідноченню обчислювальної складності та необхідної точності знайдених векторів, щзо характеризують рух безпілотного літального апарату. Комбінування прийомів та алгоритмів різної категорії в рамках класу блокових методів дозволяє побудувати адаптивні алгоритми оцінки руху, щяо володіють заданими властивостями і можуть бути реалізовані апаратно. Розглянуті методи обробки зображення можуть застосовуватися як ще один додатковий засіб автономної корекції інериійних навігаційних систем в додаток до супутникових навігаційних систем. Такий підхід дозволяє ефективно протидіяти джерелам безпеки й протидї та підвищувати ефективність використання та зменшення економічних витрат на експлуатацію безпілотних літальних апаратів.
\end{abstract}

Ключові слова: БПЛА, інформаціийний потік, вектор руху, поле руху, метод порівняння блоків.

\section{Вступ}

Постановка проблеми. Використання безпілотних літальних апаратів потребує розробки та вдосконалення підходів до розробки систем, що регулюють та забезпечують можливість автономного управління та сприяють безпеці виконання польотів. Це пов'язане з тим, що розширення кола завдань для таких пристроїв пов'язане, в першу чергу, з підвищенням їх автономності та можливості формування адаптивних моделей поведінки у динамічному середовищі. Перш за все мова йде про можливий радіоелектронний вплив, який впливає на здатність керування безпілотним літальним апаратом (БПЛА), а також про здатність автономного виконання завдання в будь-яких умовах. Таким чином необхідний пошук шляхів, що дозволяють розширити обсяг отримуваної інформації для продовження виконання завдання у будь-яких умовах та здатність БПЛА до автономного виконання завдань за призначенням навіть за умов втрати зв'язку з керуючим органом. Одним 3 можливих шляхів вирішення цього завдання $є$ можливість отримання та обробки відеоінформації в інтересах визначення параметрів руху та виробки управляючих дій.

Аналіз останніх досліджень і публікацій. Дослідження процесу автоматичного планування та корегування маршрутів польоту БПЛА при виконанні завдань за призначенням може проводитися за допомогою наступних методів: системного аналізу, теорії ймовірності, математичного моделювання, елементів штучного інтелекту, сучасних інформаційних технологій. Існуючі моделі та методи корегування маршруту польоту БПЛА при виконанні різнорідних завдань характеризуються значною обчислювальною складністю [3] та потребують наявності й постійного зв'язку з супутниковою системою навігації. Виникає необхідність пошуку шляху 
вирішення завдання розробки методу корегування параметрів польоту БПЛА з використанням наявних джерел оптичної інформації на борту літального апарату, що підвищить безпеку польотів та здатність виконати завдання таким апаратом. Теоретичною основою розробки методу є роботи з аналізу відеоінформації та виробки адаптивних команд управління на основі отриманих даних [4-6]. Удосконалення методу грунтується на роботах [6-9].

Мета статті. Метою дослідження $є$ розробка методу навігації безпілотного літального апарату при виконанні завдань за призначенням з використанням даних підсистеми збору відеоданих, що дозволить реалізувати адаптивну систему інерційної навігації та підвищити точність виробки команд керування польотом.

\section{Виклад основного матеріалу}

На борту БПЛА реалізовано підсистему отримання відео даних. Тому в загальному випадку таку підсистему можна розглядати як джерело інформації та навести іï формальну модель.

Скористуємося лінійною моделлю відеокамери [1] і опишемо взаємозв'язок між точкою $Q(X, Y, Z)$ у просторі та іï зображенням $q(x, y, f)$ на площині зображення для подальшого врахування параметрів джерела інформації:

$$
[x, y, 1]^{T}=\frac{A[R t][X, Y, Z, 1]^{T}}{s},
$$

де $S$ - довільний масштабувальний коефіцієнт;

$[R t]$ - зовнішні параметри. Дані характеристики, а саме, обертання і перенесення, дозволяють здійснювати перерахунки світової системи координат у систему координат камери;

$$
A=\left[\begin{array}{ccc}
f_{x} & \gamma & x_{0} \\
0 & f_{y} & y_{0} \\
0 & 0 & 1
\end{array}\right] \text { - матриця внутрішніх пара- }
$$

метрів камери. Дана матриця містить координати $\left(x_{0}, y_{0}\right)$ головної точки і параметр $\gamma$, що описує асиметрію вісей зображення (кут нахилу пікселів). Отже, до матриці внутрішнього калібрування $A$ включені п'ять значущих параметрів - фокусна відстань $\left(f_{x}, f_{y}\right)$, кут нахилу пікселів $(\gamma)$ і координати головної точки $\left(x_{0}, y_{0}\right)$.

Міжкадрові перетворення можна описати по іншому. Нехай кожне положення сітки розглядається як система координат [7]. Тоді міжкадрові перетворення подаються як випадкові перетворення:

$$
(u, v)_{x y}=f(x y)=\left(f_{1}(x y), f_{2}(x y), \ldots, f_{n}(x y)\right)^{T},
$$

системи координат $\Omega_{2}$ в систему координат $\Omega_{1}$, де $n$ - розмірність сітки $\Omega$. При відомих міжкадрових зміщеннях (зсув, поворот, зміна масштабу тощо), для полегшення опису перетворення (2) задається параметрично:

$$
(u, v)_{x y}=f(x, y, \alpha) .
$$

Отримана модель дозволяє перейти до аналізу особливостей руху БПЛА та зв'язок цього руху 3 параметрами отриманих зображень.

Припустимо тепер, що рух камери - тільки обертальний. Щоб визначити рух, використовуючи оптичний потік, скористаємося методом найменших квадратів [17]. Для обертального руху оптичний потік визначається як:

$$
u_{r}=\omega_{x} x y-\omega_{y}\left(x^{2}+1\right)+\omega_{z} y, v_{r}=\omega_{x}\left(y^{2}+1\right)-\omega_{y} x y-\omega_{z} x .
$$

Два різних обертання $\vec{\omega}_{1}=\left(\omega_{x}{ }^{1}, \omega_{y}{ }^{1}, \omega_{z}{ }^{1}\right)^{T}$ та $\vec{\omega}_{2}=\left(\omega_{x}{ }^{2}, \omega_{y}{ }^{2}, \omega_{z}{ }^{2}\right)^{T}$, не можуть генерувати однаковий оптичний потік.
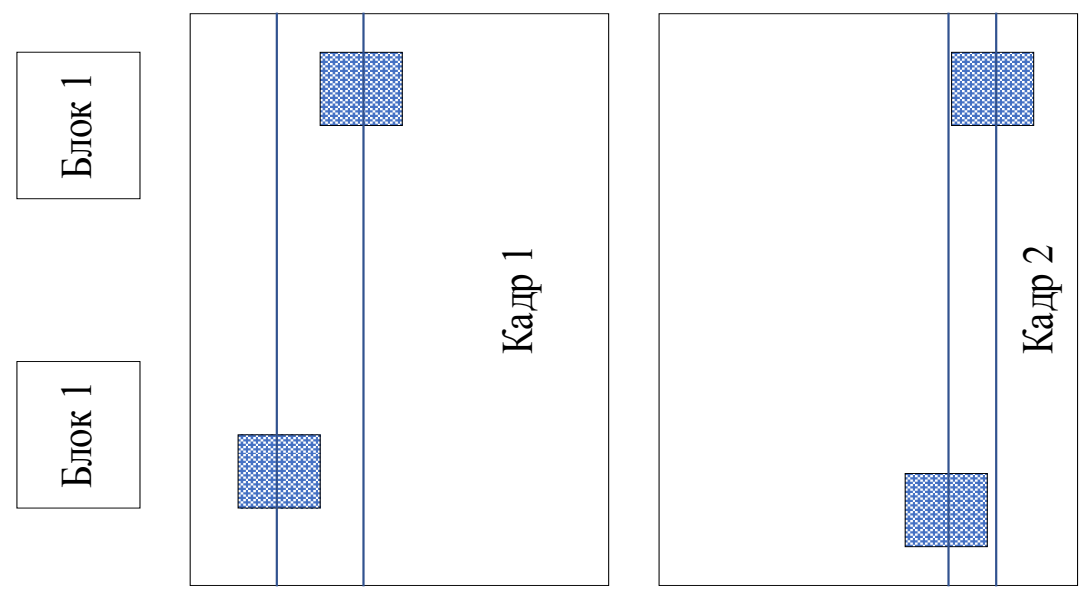

Рис. 1. Виділені фрагменти послідовності зображень
На рис. 1 показано фрагменти двох кадрів $\left(I_{n}, I_{n-1}\right)$ підстильної поверхні. Рух прямолінійний, горизонтальний, 3 креном $\quad \gamma \neq 0$. 
Як видно з рис. 2, виділені ідентичні фрагменти зображень зміщені на різну відстань, що дає змогу обчислити величину крену. У загальному випадку напрямок оптичного потоку у двох точках і його величина в одній точці визначають однозначно рух камери в чистому обертанні [18].

Критерій для оцінювання параметрів обертального руху має вигляд:

$$
\begin{gathered}
\hat{\omega}=\min _{\omega_{x}, \omega_{y}, \omega_{z}} \sum_{i, j \in B}^{n \times m} w_{i j}\left[\left(u_{i j}-\frac{\omega_{x} j+\omega_{y}\left(i+f^{2}\right)}{f}-\omega_{z} j\right)^{2}+\left(v_{i j}-\frac{\omega_{x}\left(j+f^{2}\right)+\omega_{y} i}{f}+\omega_{z} i\right)^{2}\right], \\
w_{i j}=\left\{\begin{array}{l}
1, \text { if } \operatorname{cond}\left(G_{i j}\right)<100, \\
0, \text { if } \operatorname{cond}\left(G_{i j}\right) \geq 100 .
\end{array}\right.
\end{gathered}
$$

Оскільки рух є чисто обертальним, оптичний потік не залежить від відстані до поверхні, і тому можна пропустити перший крок у запропонованому методі.

Таким чином, диференціюючи (1) відносно $\omega_{x}, \omega_{y}$ i $\omega_{z}$, отримаємо вирази, які дорівнюють нулю

$$
\begin{aligned}
& \sum_{i, j \in B}^{n \times m}\left[\left(u-u_{r}\right) i j+\left(v-v_{r}\right)\left(j^{2}+1\right)\right]=0, \\
& \sum_{i, j \in B}^{n \times m}\left[\left(u-u_{r}\right)\left(i^{2}+1\right)+\left(v-v_{r}\right) i j\right]=0, \\
& \sum_{i, j \in B}^{n \times m}\left[\left(u-u_{r}\right) j-\left(v-v_{r}\right) i\right]=0 .
\end{aligned}
$$
вираз:

Перетворивши систему рівнянь (6), отримаємо

$$
\begin{aligned}
& \bar{a} \omega_{x}+\bar{d} \omega_{y}+\bar{f} \omega_{z}=\bar{k} ; \\
& \bar{d} \omega_{x}+\bar{b} \omega_{y}+\bar{e} \omega_{z}=\bar{l} ; \\
& \bar{f} \omega_{x}+\bar{e} \omega_{y}+\bar{c} \omega_{z}=\bar{m},
\end{aligned}
$$

де:

$$
\begin{gathered}
\bar{a}=\sum_{i, j \in B}^{n \times m}\left[i^{2} j^{2}+\left(j^{2}+1\right)^{2}\right], \\
\bar{b}=\sum_{i, j \in B}^{n \times m}\left[\left(i^{2}+1\right)^{2}+i^{2} j^{2}\right], \\
\bar{c}=\sum_{i, j \in B}^{n \times m}\left[i^{2}+j^{2}\right], \\
\bar{d}=\sum_{i, j \in B}^{n \times m}\left[i j\left(i^{2}+j^{2}+2\right], \bar{e}=-\sum_{i, j \in B}^{n \times m} j,\right. \\
\bar{f}=\sum_{i, j \in B}^{n \times m} i, \bar{k}=\sum_{i, j \in B}^{n \times m}\left[u i j+v\left(j^{2}+1\right)\right], \\
\bar{l}=-\sum_{i, j \in B}^{n \times m}\left[u\left(i^{2}+1\right)+v i j\right], \bar{m}=\sum_{i, j \in B}^{n \times m}[u j-v i] .
\end{gathered}
$$

Позначивши матрицю коефіцієнтів (7) через $M$, а вектор правих частин - через $n$ отримаємо $M \bar{\omega}=n:$

$$
M=\left(\begin{array}{lll}
\bar{a} & \bar{d} & \bar{f} \\
\bar{d} & \bar{b} & \bar{e} \\
\bar{f} & \bar{e} & \bar{c}
\end{array}\right), n=\left(\begin{array}{l}
\bar{k} \\
\bar{l} \\
\bar{m}
\end{array}\right) .
$$

Таким чином, коли матриця $M$ невироджена, можна обчислити обертання як $\omega=M^{-1} n$.

Розглянемо метод для визначення руху камери за даними оптичного джерела інформації, коли апріорні припущення про рух відсутні.

Приймемо, що $Z_{1}$ i $Z_{2}$ - дві поверхні, а швидкості: $T_{1}=\left(T_{x}^{1}, T_{y}^{1}, T_{z}^{1}\right)^{T}$ і $T_{2}=\left(T_{x}^{2}, T_{y}^{2}, T_{z}^{2}\right)^{T}$ визначають два різні рухи камери.

Нехай відповідні пари $Z_{1}$ і $T_{1}$ та $Z_{2}$ і $T_{2}$ генерують той самий оптичний потік.

Тоді:

$$
\begin{aligned}
& u_{t}=\left(-T_{x}^{1}+x T_{z}^{1}\right) / Z ; \\
& v_{t}=\left(-T_{y}^{1}+y T_{z}^{1}\right) / Z ; \\
& u_{t}=\left(-T_{x}^{2}+x T_{z}^{2}\right) / Z ; \\
& v_{t}=\left(-T_{y}^{2}+y T_{z}^{2}\right) / Z .
\end{aligned}
$$

Вирішимо мінімізаційні завдання при обмеженні $T_{x}^{2}+T_{y}{ }^{2}+T_{z}^{2}=1$. Наведені нижче рівняння $\epsilon$ поліномами від невідомих $T_{x}, T_{y}, T_{z}, \omega_{x}, \omega_{y}$ i $\omega_{z}$ та можуть бути вирішені стандартними ітераційними методами, такими, як метод Ньютона або метод Берстоу [19-20].

Першим кроком є диференціювання виразу відносно $Z$ і прирівнювання отриманого виразу до нуля:

$$
Z=\frac{\alpha^{2}+\beta^{2}}{\left(u-u_{r}\right) \alpha+\left(v-v_{r}\right) \beta} .
$$

Уведемо множник Лагранжа $\lambda$ та критерій для оцінювання параметрів змішаного руху, який визначається як: 


$$
\begin{gathered}
\hat{V}=\min _{\substack{T_{x}, T_{y}, T_{z} \\
\omega_{x}, \omega_{y}, \omega_{z}}} \sum_{i, j \in B}^{n \times m} \mathrm{w}_{i j}\left[\left(u_{i j}-\frac{\omega_{x} j+\omega_{y}\left(i+f^{2}\right)}{f}-\omega_{z} j\right) \beta+\left(v_{i j}-\frac{\omega_{x}\left(j+f^{2}\right)+\omega_{y} i}{f}+\omega_{z} i\right) \alpha\right]^{2}+\lambda\left(T_{x}+T_{y}+T_{z-1}\right), \\
\mathrm{w}_{i j}=\left\{\begin{array}{l}
1, \text { if } \operatorname{cond}\left(G_{i j}\right)<100, \\
0, \text { if } \operatorname{cond}\left(G_{i j}\right) \geq 100 .
\end{array}\right.
\end{gathered}
$$

Рівняння, які необхідно розв'язати, щоб визначити параметри руху, одержимо за допомогою диференціювання:

$$
\begin{aligned}
& \sum_{i, j \in B}^{n \times m}\left[\left(u-u_{r}\right) \beta-\left(v-v_{r}\right) \alpha\right]\left[-i j \beta+\left(j^{2}+1\right) \alpha\right]=0 ; \\
& \sum_{i, j \in B}^{n \times m}\left[\left(u-u_{r}\right) \beta-\left(v-v_{r}\right) \alpha\right]\left[\left(i^{2}+1\right) \beta-i j \alpha\right]=0 ; \\
& \sum_{i, j \in B}^{n \times m}\left[\left(u-u_{r}\right) \beta-\left(v-v_{r}\right) \alpha\right][j \beta+i \alpha]=0 ; \\
& \sum_{i, j \in B}^{n \times m}\left[\left(u-u_{r}\right) \beta-\left(v-v_{r}\right) \alpha\right]\left[v-v_{r}\right]+\lambda T_{x}=0 ; \\
& \sum_{i, j \in B}^{n \times m}\left[\left(u-u_{r}\right) \beta-\left(v-v_{r}\right) \alpha\right]\left[u-u_{r}\right]+\lambda T_{y}=0 ; \\
& \sum_{i, j \in B}^{n \times m}\left[\left(u-u_{r}\right) \beta-\left(v-v_{r}\right) \alpha\right]\left[\left(u-u_{r}\right) j+\left(v-v_{r}\right) i\right]+ \\
& +\lambda T_{z}=0 ; \\
& T_{x}+T_{y}+T_{z}=1 \text {. }
\end{aligned}
$$

Перші три рівняння є лінійними в $\omega_{x}, \omega_{y}$ i $\omega_{z}$,
3 яких параметри можуть бути визначені однозначно в одиницях $T_{x}, T_{y}$ i $T_{z}$. Тоді можна визначити $T_{x}, T_{y}$ i $T_{z}$, числовим методом 3 останніх чотирьох рівнянь.

На рис. 2 зображено структурну схему системи побудови поля руху для визначення параметрів руху. На рисунку видно, що система забезпечення навігації використувує дані трьох незалежних джерел визначення параметрів руху: інерційні вимірювальні прилади, систему супутникової навігації та оптичні датчики, за допомогою яких будується поле векторів руху.

За допомогою фільтра Калмана забезпечується адаптація команд керування до змін обстановки, в якій рухається безпілотна система.

Для дослідження точності роботи запропонованого підходу було розроблено програму в системі моделювання Matlab. Ефект польоту відтворювався зміною координат та орієнтацією камер, при цьому координати підстильної поверхні не змінювалися. При імітації процесу польоту випадковим чином змінювалися яскравість та насиченість зображення, що відтворює роботу реальних оптичних систем.

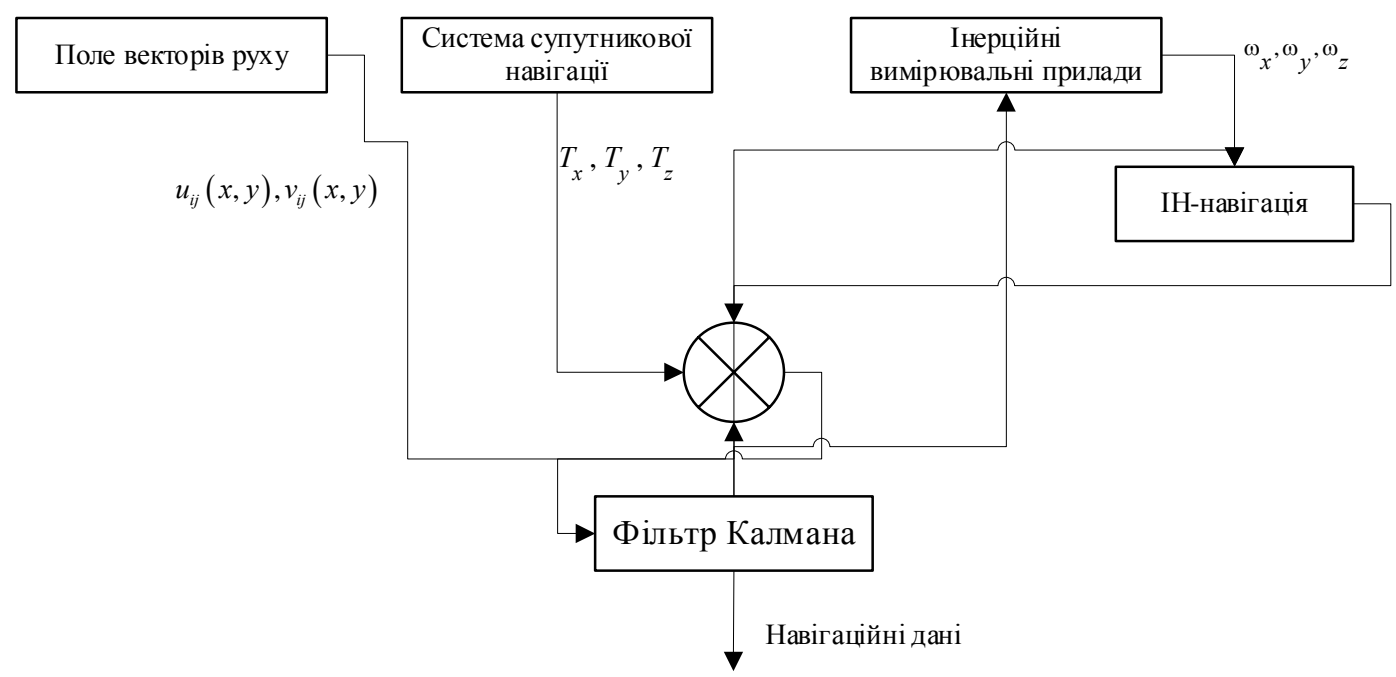

Рис. 2. Структура системи забезпечення навігаціі

На рис. 3 зображено структуру методу виробки управляючих впливів на основі оброблення даних від оптичного джерела інформації. Дослідження моделі руху проводилося на дванадцяти зображеннях підстильної поверхні з різними показниками текстури [25]. Для порівняння розрахунок поступальної швидкості руху проводився з використанням запропонованого методу і стандартного методу, що базується на рівноточних вимірах. 


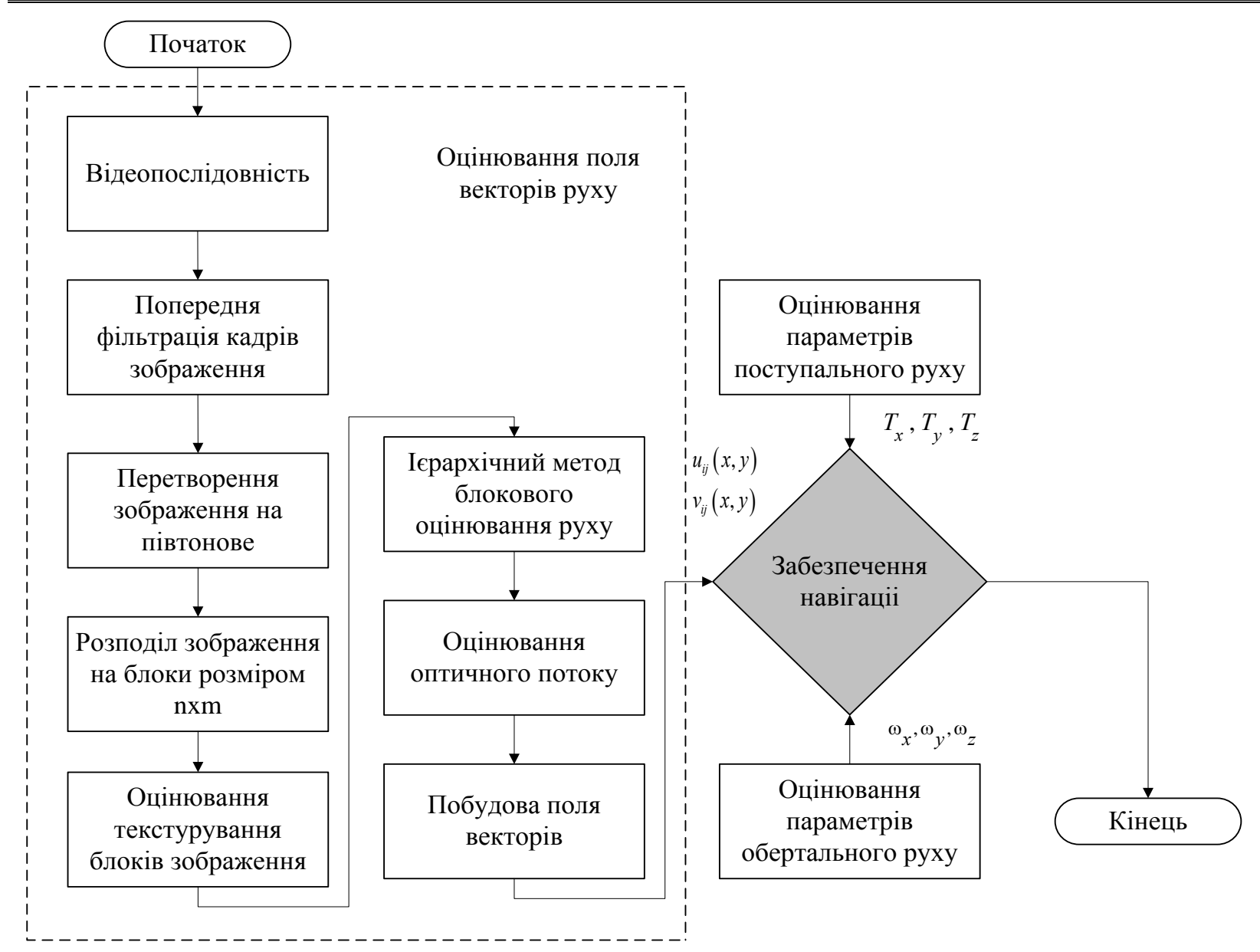

Рис. 3. Структура методу виробки управляючих впливів на основі оброблення даних від оптичного джерела інформації

У якості початкових даних моделювання використовувалися: середня швидкість - 16 м/с, висота руху камери - 100 м, кут огляду камери - 90 град., фокусна відстань - 1 мм, розмір ПЗС матриці 256x256 пікселів, частота обробки кадрів 30 кадр./с. Вимірювання поступальної швидкості руху здійснювалося 3 компенсацією обертального руху при зміні кутових швидкостей $Y, X, Z=$ [- 10:10]. Рух камери на тестовому зображенню показано на рис. 4.

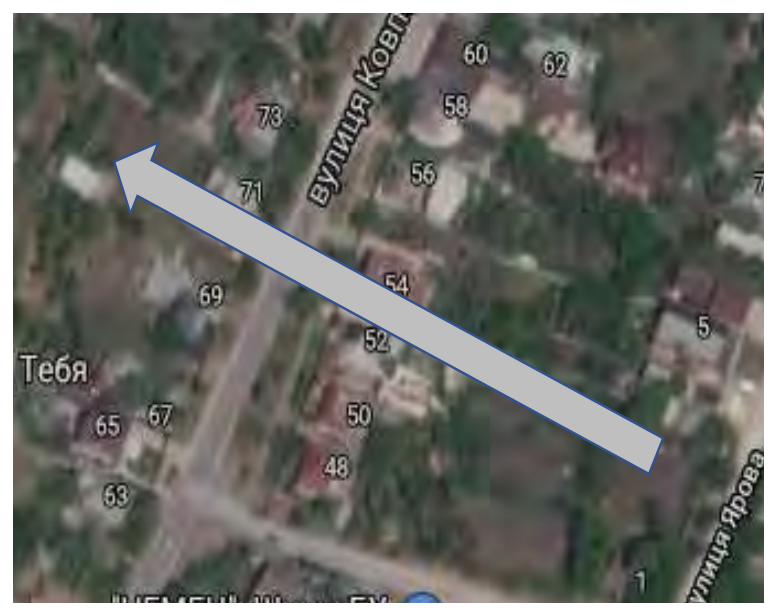

Рис. 4. Траєкторія руху відеокамери
На рис. 5 зображено поточний кадр, для якого визначається область інтересу та виконується процедура пошуку векторів руху.

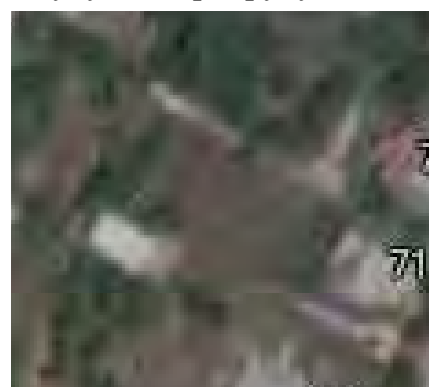

Рис. 5. Поточний кадр відеопослідовності, червоною областю позначений регіон, для якого виконувалася процедура пошуку векторів руху

На рис. 6 представлена відеопослідовність, у якій для попереднього i поточного кадрів виконується процедура пошуку векторів руху методом зважувального оброблення блоків зображення та з використанням текстурного аналізу. Вектор руху визначено в областях з числом обумовленості від 1 до 10, в областях при cond більше 10, блоки вважаються помилково виявленими й ігноруються (вектор руху дорівнює 0). 


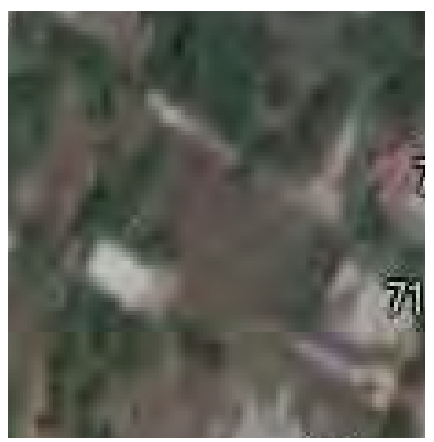

a - попередній кадр

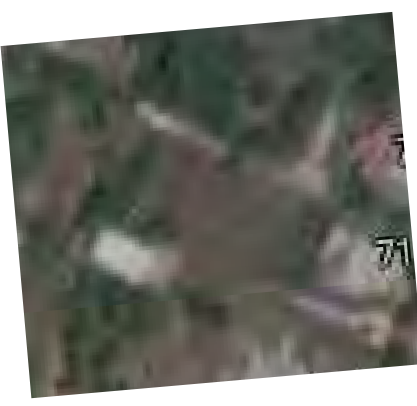

б - поточний кадр

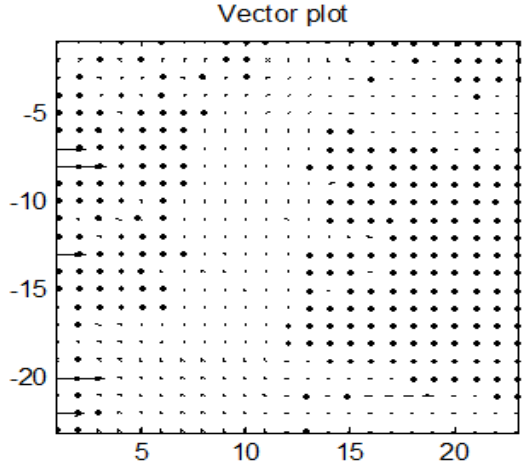

в - поле векторів руху

Рис. 6. Розрахунок поля векторів для поточного і попереднього кадрів

На основі отриманих результатів оцінювання поступальної швидкості можна зробити аналіз точності запропонованого методу.

На рис. 7 дійсна поступальна швидкість (д1) позначено суцільною синьою лінією, розрахована поступальна швидкість стандартним методом (д2) суцільною зеленою лінією, а розрахована поступальна швидкість розробленим методом визначення поля векторів руху (д3) - суцільною червоною лінією.

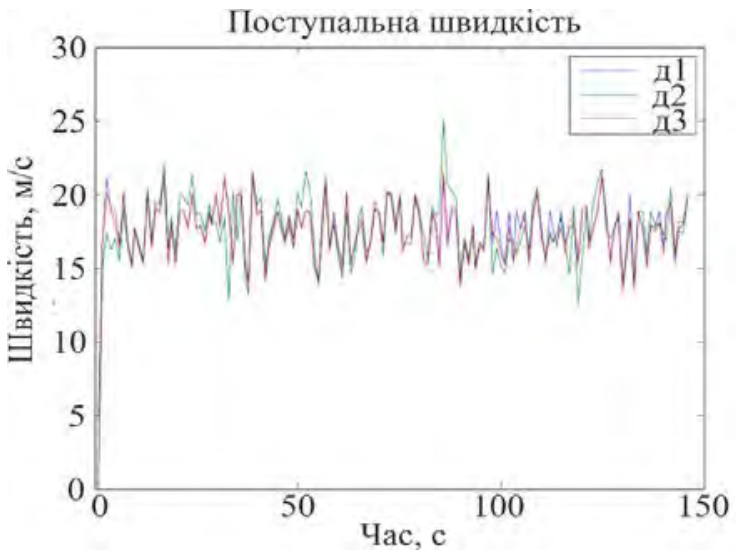

Рис. 7. Поступальна швидкість руху камери

На рис. 8 та на рис. 9 показано похибки оцінювання поступальної швидкості, визначені стандартним та розробленим методом оцінювання поля векторів руху.

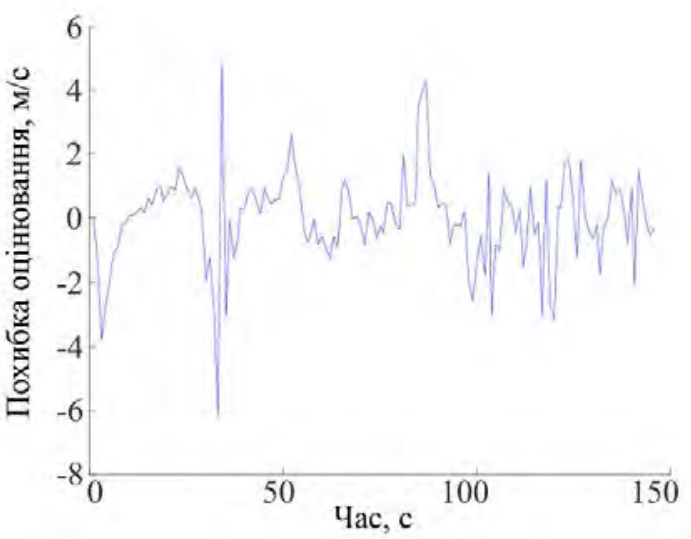

Рис. 8. Похибки оцінювання поступальної швидкості стандартного методу

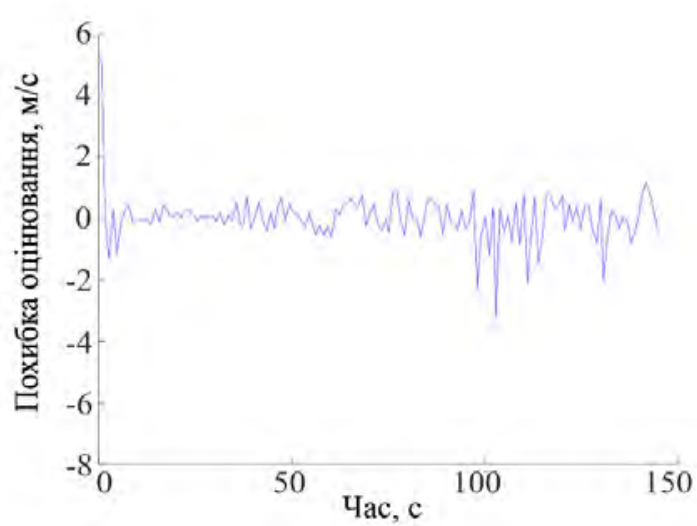

Рис. 9. Похибки оцінювання поступальної швидкості розробленим методом

\section{Висновки}

Запропонований метод управління рухом та орієнтацією на основі даних отриманих з оптичного джерела інформації безпілотного літального апарату. Оцінена ефективність запропонованого методу шляхом чисельного моделювання тестових зображень для знімків 3 поганою і хорошою текстурованою поверхнею.

Результати застосування розробленого методу показали, що середнє оцінене значення похибки та стандартне відхилення похибки визначення поступальної швидкості на текстурованих зображеннях приблизно у два рази краще показників, отриманих стандартними методами.

Проведене моделювання для різних видів підстильної поверхні підтвердили, що при використанні текстурного методу слабка текстурованість майже не впливає на визначення параметрів швидкості. Похибки оцінених параметрів порівняні 3 похибками супутникових систем навігації.

Встановлено, що результати, отримані за допомогою розроблених методів, можуть бути використані для самостійного визначення параметрів руху БПЛА в районах зі слабким або відсутнім сигналом GNSS. Запропонований метод може скласти основу технології коригування даних супутникової та інерційної систем навігації. 


\section{Список літератури}

1. Chao H. Remote Sensing and Actuation Using Unmanned Vehicles UAVs / H. Chao, Y.Q. Chen. - Hoboken, New Jersey: Wiley-IEEE Press. - 2012. - 232 p.

2. Бурый А.С. Подход к построению систем поддержки принятия решений при управлении беспилотными летательными аппаратами / А.С. Бурый, М.А. Шевкунов // Транспортное дело России. - 2015. - № 6. - С. 22-26.

3. Тристан А.В. Математичні моделі та методи планування повітряної розвідки рухомих й стаціонарних об'єктів 3 застосуванням безпілотних літальних апаратів / А.В. Тристан., А.О. Бережний, І.М. Крижанівський // Збірник матеріалів VII-ої міжнародної науково-технічної конференції “Проблеми інформатизації”. - Черкаси, 13-15 листопада 2019 р. T. 3. - C. 41.

4. Kim J. Dual optic-flow integrated navigation for small-scale flying robots / J. Kim, G. Brambley // Proceedings of the Australasian Conference on Robotics and Automation. - Brisbane, 2007.

5. Буч Г. Язык UML. Руководство пользователя: пер. с англ. / Г. Буч, Д. Рамбо, А. Джекобсон. - М.: ДМК, 2000. $432 \mathrm{c}$.

6. Sanada A. Self-localization of an omnidirectional mobile robot based on an optical flow sensor / A. Sanada, K. Ishii, T. Yagi // Journal of Bionic Engineering. - 2010. - No. 7. - P. 172-176.

7. Моисеев В.С. Прикладная теория управления беспилотными летательными аппаратами: монография / В.С. Моисеев. - Казань: ГБУ РЦМКО, 2013. - 768 с.

8. Тимочко А.И. Метод дешифрирования аэроснимков на основе при знакового пространства / А.И. Тимочко, С.А. Олизаренко, О.Ю. Лавров // Системи обробки інформації. - 2015. - № 1(126). - С. 84-87.

9. Павленко М.А. Метод решения задачи автоматизации процесса выбора маршрута полета ударной авиации / М.А. Павленко, Д.А. Пархоменко // Наука і техніка Повітряних Сил Збройних Сил України. - № 2(15). - 2014. - С. 71-74.

10. Сидоркина И.Г. Системы искусственного интеллекта / И.Г. Сидоркина. - М.: КноРус, 2011. - 248 с.

\section{References}

1. Chao, H. and Chen, Y.Q. (2012), Remote Sensing and Actuation Using Unmanned Vehicles UAVs, Hoboken, New Jersey: Wiley-IEEE Press, $232 \mathrm{p}$.

2. Buryi, A.S. and Shevkunov, M.A. (2015), "Podkhod k postroeniyu system podderzhki prinyatiya reshenii pri upravlenii bespilotnymi letatel'nymi apparatami” [Approach to the construction of decision support systems for the management of unmanned aerial vehicles], Transport business in Russia, No. 6, pp. 22-26.

3. Trystan, A.V., Berezhnyi, A.O. and Kryzhanivskyi, I.M. (2019), "Matematychni modeli ta metody planuvannia povitrianoi rozvidky rukhomykh y statsionarnykh obiektiv z zastosuvanniam bezpilotnykh litalnykh aparativ” [Mathematical models and planning methods for aerial reconnaissance of mobile and stationary objects using unmanned aerial vehicles], Proceedings of the VII International Scientific and Technical Conference "Problems of Informatization", 13-15 November, Vol. 3, Cherkasy, Ukraine, pp. 41-42.

4. Kim, J. and Brambley, G. (2007), Dual optic-flow integrated navigation for small-scale flying robots, Proceedings of the Australasian Conference on Robotics and Automation, Brisbane, Australia.

5. Buch, G., Rambo, D. and Dzhekobson, A. (2000), “Yazyk UML. Rukovodstvo pol'zovatelya” [UML language. User's manual], DMK, Moscow, $432 \mathrm{p}$.

6. Sanada, A., Ishii, K. and Yagi, T. (2010), Self-localization of an omnidirectional mobile robot based on an optical flow sensor, Journal of Bionic Engineering, No. 7, pp. 172-176.

7. Moiseev, V.S. (2013), “Prikladnaya teoriya upravleniya bespilotnymi letatel'nymi apparatami” [Applied Control Theory of Unmanned Aerial Vehicles], GBU RTsMKO, Kazan, 768 p.

8. Timochko, A.I., Olizarenko, S.A. and Lavrov, O.Yu. (2015), "Metod deshifrirovaniya aerosnimkov na osnove priznakovogo prostranstva” [Aerial photographs decryption method based on feature space], Information Processing Systems, No. 1(126), pp. 84-87.

9. Pavlenko, M. and Parchomenko, D. (2014), "Metod resheniya zadachi avtomatizatsii protsessa vybora marshruta poleta udarnoy aviatsii” [The method of solving the problem of automating the process of selecting the flight route of attack aircraft], Science and Technology of the Air Force of Ukraine, No. 2(15), pp. 71-74.

10. Sidorkina, I.G. (2011), "Sistemy iskusstvennogo intellekta” [Artificial intelligence systems], KnoRus, Moscow, 248 p.

Надійшла до редколегії 30.03.2020

Схвалена до друку 14.04.2020

\section{Вidомості про авторів:}

\section{Кривоножко Анатолій Миколайович}

Командувач

Повітряного Командування “Центр”,

Васильків, Україна

https://orcid.org/0000-0002-1470-7301

\section{Information about the authors:}

\author{
Anatolii Krivonozhko \\ Commander \\ of the Air Command "Center", \\ Vasylkiv, Ukraine \\ https://orcid.org/0000-0002-1470-7301
}


Романюк Валерій Миколайович

Головний інспектор Повітряних Сил

Головної інспекції Міністерства оборони, Київ, Україна

https://orcid.org/0000-0002-1204-9384

\section{Дудко Марина Валеріївна}

науковий співробітник

Харківського національного університету

Повітряних Сил ім. І. Кожедуба,

Харків, Україна

http://orcid.org/0000-0002-2010-1779

\section{Руденко Дмитро Васильович}

кандидат технічних наук доцент

Української інженерно-педагогічної академії,

Харків, Україна

https://orcid.org/0000-0003-0561-4194

\author{
Valerii Romaniuk \\ Chief Inspector of the Air Force \\ of Chief Inspectorate of the Ministry of Defense, \\ Kyiv, Ukraine \\ https://orcid.org/0000-0002-1204-9384
}

\section{Maryna Dudko}

Research Associate

of Ivan Kozhedub Kharkiv

National Air Force University,

Kharkiv, Ukraine

https://orcid.org/0000-0002-2010-1779

\section{Dmytro Rudenko}

Candidate of Technical Sciences Associate Professor of Ukrainian Engineering and Pedagogical Academy, Kharkiv, Ukraine

https://orcid.org/0000-0003-0561-4194

\title{
МЕТОД НАВИГАЦИИ БЕСПИЛОТНЫХ ЛЕТАТЕЛЬНЫХ АППАРАТОВ ПРИ ВЫПОЛНЕНИИ ЗАДАЧ
}

\author{
А.Н. Кривоножко, В.Н. Романюк, М.В. Дудко, Д.В. Руденко
}

Использование беспилотных летательных аппаратов во время выполнения разнородных задач по назначению требует разработки дополнительных механизмов защиты их от воздействия радиоэлектронных помех, погодных условий и повышения безопасности полетов в зоне выполнения задач. Одним из подходов уменьшения уязвимости беспилотного летательного аппарата является использование инериионных средств навигачии. Дополнительно к ним могут использоваться методы обработки изображений, получаемые подсистемой оптического ориентирования, для оценки параметров движения и выработки управляющих воздействий. В статье предложен метод навигаџии беспилотного летательного аппарата для оченки динамических параметров движения по данным, полученным оптической подсистемой навигачии. В данной работе предложен адаптивный метод определения параметров вектора движения беспилотного летательного аппарата, реализующего прочедуру адаптивного изменения размера и стратегию поиска вектора движения, зависящих от структуры блока изображения и его свойств. Проведен анализ существующих методов оценки параметров вектора движения на основе оптических данных. Проведено формальное описание оптического потока и определена процедура его получения. Определен состав алгоритмов для обработки оптического потока данных. Обоснован выбор блочного алгоритма оченки движения. Блочные алгоритмы являются компромиссным решением по соотношению вычислительной сложности и требуемой точности найденных векторов, характеризующих движение беспилотного летательного аппарата. Комбинирование приемов и алгоритмов различной категории в рамках класса блочных методов позволяет построить адаптивные алгоритмы оиенки движения, обладающих заданными свойствами, и могут быть реализованы аппаратно. Рассмотрены методы обработки изображения могут применяться как еще один дополнительный способ автономной коррекиии инерииальных навигационных систем в дополнение к спутниковым навигационным системам. Такой подход позволяет эффективно противодействовать источникам опасности и противодействия и повышать эффективность использования, а также снизить экономические затраты на эксплуатацию беспилотных летательных аппаратов.

Ключевые слова: БПЛА, информационный поток, вектор движения, поле движения, метод сравнения блоков.

\section{METHOD OF NAVIGATION OF AN UNMANNED AIRCRAFT WHEN PERFORMING TASKS FOR THE PURPOSE}

\section{A. Krivonozhko, V. Romaniuk, M. Dudko, D. Rudenko}

The use of unmanned aerial vehicles during the performance of heterogeneous tasks for their intended purpose requires the development of additional mechanisms to protect them from the effects of electronic interference, weather conditions and increase flight safety in the area of performance of tasks. One approach to reducing the vulnerability of an unmanned aerial vehicle is to use inertial navigation aids. In addition, image processing methods obtained by the optical orientation subsystem can be used to estimate motion parameters and generate control effects. The article proposes a method of unmanned aerial vehicle navigation for estimating dynamic motion parameters according to the data obtained by the optical subsystem. This paper proposes an adaptive method for determining the parameters of the motion vector of an unmanned aerial vehicle, which implements the procedure of adaptive resizing and the strategy of finding the motion vector, which depends on the structure of the image unit and its properties. The analysis of existing methods of estimation of motion vector parameters on the basis of optical data processing is carried out. A formal description of the optical flux is performed and the procedure for its production is determined. The composition of algorithms for optical flow processing is determined. The choice of block motion estimation algorithms is substantiated. Block algorithms are a profitable compromise in the ratio of computational complexity and the required accuracy of the found vectors that characterize the motion of an unmanned aerial vehicle. Combining techniques and algorithms of different categories within the class of block methods allows you to build adaptive motion estimation algorithms that have given properties and can be implemented in hardware. The considered methods of image processing can be used as another additional means of autonomous correction of inertial navigation systems in addition to satellite navigation systems. This approach allows to effectively counteract the sources of security and counteraction and increase the efficiency of use and reduce the economic costs of operating unmanned aerial vehicles.

Keywords: UAV, information flow, motion vector, motion field, block comparison method. 